\title{
Refugee Status Determination: A Comparative Study
}

\author{
Christopher Avery, "Refugee Status Decision-Making: The Systems of Ten Countries", \\ Stanford Journal of International Law, Volume 19; 2, Summer, 1983
}

This is the best article on the status determination process. Packed with information and analytic data, the article compares the legal status of the process, the procedures, the nature of the initial interview, the decision-making apparatus and practice, the rights of the claimants, training procedures and resources and the whole process of review with a brief historical update and evaluation at the end of the analysis of each country. It is a must for anyone interested in the status determination system. Although organized on a country-by-country basis, I found it more helpful to read and compare each stage of the procedure in all the countries.

What the comparative study provides is a checklist of how, in fact, an excellent status determination process would be constituted. First, it would be embedded in law and would apply to all refugee claimants regardless of origin. The Italian system is clearly discriminatory in excluding non-European refugee claimants. Similarly, the process at the border claim point (or internally) is crucial. Can there be a summary expulsion by an immigration officer after a brief interview? Is the interview recorded? Is the officer trained? Is the applicant entitled to counsel? The worst situation seems to be that of Sweden, closely followed by Switzerland's policy and practice. In those countries the decisions of the border officers, who are inadequately trained, are made without record, without counsel, and without appeal. The United States' practice of informally persuading claimants to accept voluntary departure is almost as bad. The new West German procedure allows guards to deny entry if they determine that the applicant has already found protection in another country, has previously been denied refugee status and has no new evidence. The claimant can only appeal from outside Germany.

The best situations, for example in France, are found where the officers only refer claimants to other specialized groups. The standard practice of Australia, Belgium and the U.K. (though not protected in the latter country by law), and Canada, is to refer claims to a higher authority. In sum, a good system of refugee status determination does not place the responsibility for any decision making onto officers who are responsible for enforcement of immigration laws, whether they are immigration officers, alien policy or come under another rubric.

The real question of quality then depends on the nature of the initial interview, whether the claimant can be present and is entitled to counsel, and whether the interviewer is well trained, knowledgeable about procedures and human rights situations in countries of origin. To be effective, such interviewers must have available the resources of a specialized library and documentation centre. It is clearly preferable if the interviewer is not an immigration, border or alien police officer, but is specialized to deal only with refugee claimants. Further, the training and information resources available to the initial-hearing officer are crucial to the fairness of the procedures. The ideal situation is to be found in France where the claim is referred directly to the Office for the Protection of Refugees and Stateless Persons (OFPRA). The worst situations are in Sweden and Switzerland, where the officers may be well trained in procedures, but may be ignorant of human rights situations in countries of origin; a problem compounded when the officers possess arbitrary powers. Australia and Canada have systems that fall somewhere in between, where the interviewing officers have been helped with improved training and information. In some areas in Canada oral hearings have been instituted on a trial basis. The situation in Belgium is slightly better; the original interview merely determines basic data and can decide inadmissible claims under very narrow criteria (subject to appeal). Better yet the initial interviewers in the U.K establish only basic information. The American Immigration and Naturaliza tion Service (INS) examinations are closer to those of Sweden and Switzer land. The officers receive no training in refugee law or procedures and are poorly informed on human rights situ ations abroad.

Aside from the powers and training o the border police or immigration offi cers, the ideal way to maximize the training and minimize the powers o officers and ensure the rights of claim? ants, is to establish excellent training procedures and a structure which en sures the independence of the decision making body. Again, France provides the ideal in the Office Français de Protection des Réfugiés. Although it is a public authority attached to the Ministry of Foreign Affairs, it has its own legal personality and financial and administrative autonomy. The directo is a senior diplomat appointed by the Foreign Affairs ministry in consultation with other ministries. The director's practice is to appoint officers who are attorneys with extensive experience in human rights law for one-year renew able terms. OFPRA has an Advisory Council consisting of a chairman from the Ministry of Foreign Affairs, five representatives from other relevan: ministries, an NGO representative and a UNHCR representative in attendance. The Advisory Council approves th budget, advises on determination o refugee status, proposes improvement and appoints one member to the $A p_{4}$ peals Commission. The latter consist: of a chairman appointed by the equi valent of France's quasi-ombudsmar office as well as a UNHCR representa tive. Thus, its procedural structure is based on both fairness and the appear. ance of fairness. However, the pro cedure is somewhat weak in supplying information to the officers, althoug the training resources are adequate particularly at the stage of initial dete 
mination. The claimant has the right to appear at both the initial and appellant stages.

Belgium has an equally independent procedure, where decision making has been delegated to the UNHCR. This procedure is criticized, as well, because of the UNHCR's necessary dealings with the claimant's government of origin. Australia's system proves almost as good, for despite the fact that decision making power is vested finally in the Ministry of Immigration and Ethnic Affairs, in practice it is delegated to the Determination of Refugee Status Committee (DORS) with representatives from various ministries and the UNHCR. However, the candidate may not appear before this body. This is a serious flaw. DORS is equivalent to the Canadian Refugee Status Advisory Committee (RSAC), which is praised for including citizens who are not civil servants. The article does not mention, however, that positions on the committee are sometimes patronage appointments. Canada is also praised for the initiation of oral hearings at the preliminary stage. The seminars and new resource library are all beneficial, but the absence of the right of a claimant to appear before RSAC is viewed as a deficiency.

The West German Federal Agency for the Recognition of Foreign Refugees does interview candidates except in obviously warranted cases. The selection of the hearing officers (by exam) and the presentation of seminars every six months are very helpful in ensuring well-qualified hearing officers. Given Italy's restriction to Europeans, Italy's Joint Eligibility Commission is an excellent structure, especially since all claimants are interviewed. It generally operates by consensus and consists of representatives from the UNHCR (with two votes), the Ministry of Interior and the Ministry of Foreign Affairs (each with a single vote). The lack of a library or documentation centre is a serious $\{$ deficiency. Similarly, if a claimant can manage to get past the Alien Police in Sweden, the procedure beyond that point is very fair since the determining body is autonomous of government and constituted by a non-political parliamentary committee. The committee's decisions can be overturned by government policy in order to ensure that the refugee claimant is not returned to his country of origin. In fact, the unfairness practiced by the Alien Police at the preliminary stages is offset by an equally unbalanced process in the opposite direction at the appeal level, where decisions are made more on the basis of the publicity given to a case rather than on its merits.

Switzerland has no equivalent procedure to correct imbalance. Initial arbitrary power is given to the Alien Police. The Federal Police Office in Bern, which reviews documents and the transcripts provided by the Cantonal Aliens Police has the benefit of young attorneys who are experienced, but who lack training in refugee issues. The Swiss process, however, does have the advantage of a resource centre, but there is no allowance for input from the UNHCR. The applicants are granted an oral hearing by right (in contrast to Canada where it is only a matter of experiment), an interpreter and a representative from a refugee aid organization. The latter, however, can only be present as an observer rather than an advocate. An appeal goes to the Justice Ministry and then to the Federal Council based only on the written transcript.

It is obvious that the crucial elements that ensure fairness imply a system of specialized, well-trained officers with a resource library and the input of independent advocates, complemented by a claimant's right to be present at an oral hearing at the initial phase of the procedure. Appeals to detached and disinterested parties at a second level is a double but secondary level of protection. Thus, the U.K. system is good insofar as decisions are in the hands of a specialized refugee unit with effective training procedures, but is weak in that the officers are not well informed on human rights situations abroad (although this situation is being corrected). The process is weakened further by the lack of routine oral hearings. The appeals procedure of an Immigration Appeals Adjudicator specialized in asylum cases equipped with the automatic right of the claimant to have an oral hearing would ensure that the British system is reasonably fair. This is supplemented by a second level of appeal to the Immigration Appeals Tribunal. However, it is clear that the major weakness and strength depends on the resources, quality, independence and fairness at the initial level of decision making. The input of UNHCR is also crucial in assessing this fairness.

Despite some strengths, the American procedures possess a different set of weaknesses beyond the initial discouragement provided by the border police. The fact that the INS officers and immigration judges do not specialize in refugee cases is a drawback. These employees are civil servants, and few are attorneys. Two-week training sessions are inadequate, particularly with respect to refugee law and fair interview procedures. Training is nonexistent on the subject of human rights situations in the countries of origin. The file prepared by the initial interviewer is generally inadequate, the decision by the district director based on the written submissions with an advisory opinion by the State Department, cannot help but be insufficient as well as appear to be blatantly unfair. Most disconcerting is the "enforcement mentality" of the decision-making apparatus, particularly when the decision-making officer began his rise through the civil service from a position in the border patrol. The courts, in the case of Haitians, have found INS to have acted in a discriminating manner. Though the officers have access to human rights information, the practice is to rely on State Department advice and not seek out independent sources of information.

Clearly, independence, training in refugee law and interview procedures and access to independent sources of information are all crucial to the initial level of decision making. The independent input by UNHCR is important as is the right of the appellant to an oral hearing and the presence of an advisor. The appeal procedure should ensure a second check by a body which is seen to be independent of the enforcement process. The appeal group must be experienced and trained in refugee matters with appropriate resources available to it. 


\section{Canada's Refugee Status Determination Procedures: *}

\section{Required Elements:}

- Access to the Refugee Determination Procedure

- Efficient and Expeditious Procedures

- Oral Hearing

- Quality Decision Making

- Right to Information about the Procedure

- Right to Counsel

- Right to Interpreters

- Reasonable Time Limitations
- Compliance with Rules of Evidence

- Balance of Probability and Presumption of Credibility

- Right to Re-open Hearing

- Right to Appeal

- Procedural Safeguards for Unfounded Claims

- Guaranteed Minimum Living Standards

- Right to Family Reunification

\section{Proposed Refugee Determination Model ${ }^{*}$}

\section{REFUGEE BOARD (DETERMINATION DIVISION)}

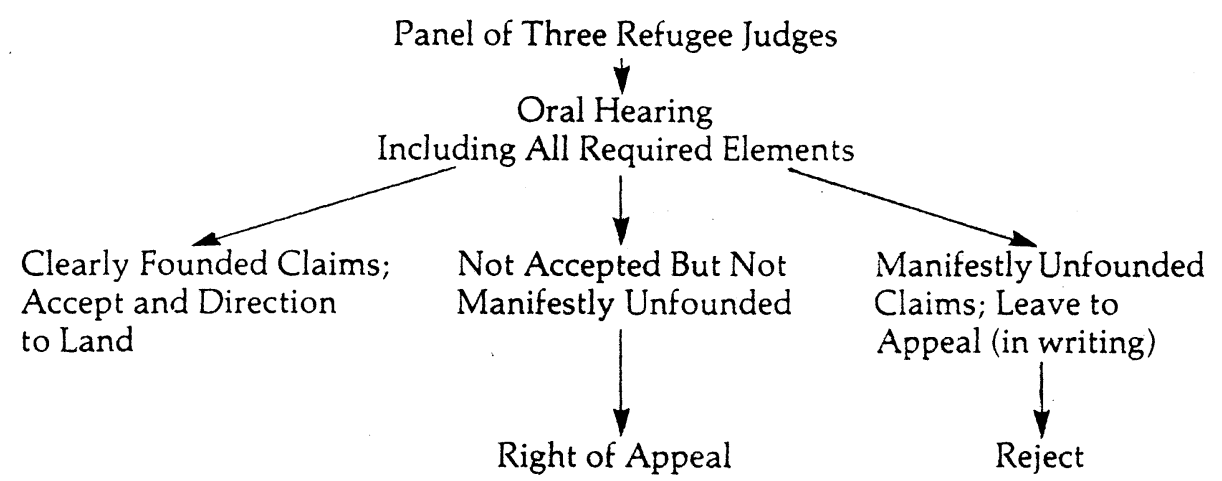

\section{REFUGEE BOARD (APPEAL DIVISION)}

One Judge

Oral Hearing

Including All Required Elements

Accept with Direction

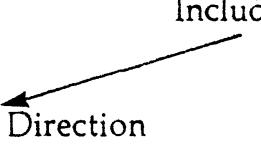

to Land

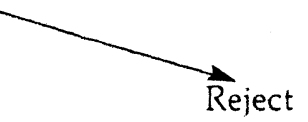

*Delegation of Concerned Legal, Church and Humanitarian Organizations to the Plaut Commission 